\title{
Temelín nuclear power plant, South Bohemia - Reference level of hydrosphere, prediction of impact, results from pre-operation period
}

\author{
E.J. Hanslik, B. Sedlarova and P. Simonek \\ T.G. Masaryk Water Research Institute, Department of Radioecology, \\ 16062 Prague 6, Czech Republic
}

\begin{abstract}
Beginning of the construction of Temelin Nuclear Power Plant (NPP) in south Bohemia (CR) dates back to 1986. It was planned that the first water-cooled reactor could be put into operation in 2001. A research project (1989-1998), funded from the national budget and carried out under supervision of the Czech Ministry of Environment, was aimed at examining pre-operational environmental conditions (a reference level) in terms of concentrations of radioactive and non-radioactive polluting substances in components of the environment, particularly in the hydrosphere, and at predicting possible impacts of future operation of Temelín NPP. Special attention paid to the hydrosphere was associated with requirements for protection of water quality in the Vltava River, which serves as drinking water resource for Prague capital. The observation and research activities continue during the following period (1999-2006) within the framework of a project sponsored by Czech Power Company. The paper summarises selected results of the projects, particularly those concerning pre-operational environmental conditions and impacts predicted for standard operation of the plant. More detailed description of the results, including possible impacts of the so called maximum project accident, is presented in [1-3]. To the date of the conference, the releases of tritium and other radionuclides from the plant into the hydrosphere were much less than the authorised limits.
\end{abstract}

\section{INTRODUCTION}

Temelin NPP is located on the upper Vltava River in south Bohemia. The Vltava is an important resource of drinking water for Prague. Its water affects also quality of the Elbe River on the territory of both the Czech Republic and the Federal Republic of Germany.

Two of the reservoirs which have been constructed on the Vltava River serve for water management purposes of Temelín NPP (see layout map in Figure 1). Water for the plant is abstracted from the Hněvkovice Reservoir (put into operation in 1991) and pumped to storage tanks with capacity of $2 \mathrm{x}$

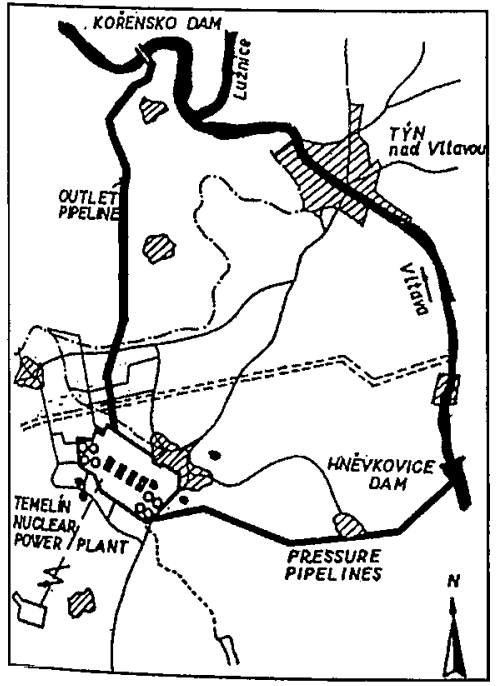

$15000 \mathrm{~m}^{3}$, from which it flows by gravity. For the operation of the two reactors, the total mean abstraction will be $16001 . \mathrm{s}^{-1}$. The plant will return $5001 . \mathrm{s}^{-1}$ (as maximum) of remaining cooling water and purified waste water. This water will be discharged into the Vltava River at the Kořensko Reservoir through hydroelectric power station located at Kořensko Dam.

The observation and assessments of pre-operational environmental conditions involved radioactive and nonradioactive polluting substances in surface water, groundwater, precipitation water, suspended solids, bottom sediments and biomass in wider environs of the Temelín NPP, and also temperature and transport conditions in the Orlik and other reservoirs built downstream from the Temelín on the Vltava River. The examination of the hydrosphere prior to the operation of Temelín NPP is particularly important in terms of radioactive substances because some of the radionuclides (such as ${ }^{3} \mathrm{H},{ }^{90} \mathrm{Sr},{ }^{134} \mathrm{Cs}$ and ${ }^{137} \mathrm{Cs}$ ) 
potentially present in effluent returns from Temelin NPP are identical to those remaining in the environment after the Chernobyl accident and tests of nuclear weapons. Determination of radionuclides was made mainly by gamaspectrometric and LSC methods described in more detail in Figure 1 Temelín NPP water supply system. reports [1-3].

Methods used in carrying out the projects were verified and recommended by the International Atomic Energy Agency in Vienna within the framework of its technical assistance organised in co-operation with the Ministry of the Environment of the CR and the State Office for Nuclear Safety [2]. These methods are described in report [3].

\section{PRE-OPERATIONAL ENVIRONMENTAL CONDITIONS}

The results of the studies involve data on levels of naturally occurring and artificial radionuclides in the environment. Chernobyl accident in 1986 and tests of nuclear weapons performed in sixties are min factors responsible for the environmental levels of artificial radionuclides. A peak after the Chernobil followed by a decrease is a typical pattern of their concentration in all of the observed components of the environment. This can be demonstrated by the following examples.

Concentrations of radionuclides in surface water have been observed in the Vltava River (upstream and downstream from Temelín) and in its main tributaries since 1990. The concentrations of radionuclides were determined from evaporation residues from large-volume (about 50 l) samples taken with frequency of four times in a year. Figure 2 shows trend curves derived from ${ }^{137} \mathrm{Cs}$ concentrations measured in the Vltava River at Hněvkovice (water abstraction for Temelín), in the Lužnice River (at Koloděje) which discharges into the Vltava upstream from Kořensko Dam, in the Otava River (at Písek) discharging into the Vltava upstream from Orlik Dam (downstream from Kořensko), and in the Vltava at Solenice (outflow from the Orlík Reservoir). We can see a decreasing trend in the concentrations at all of the above sites, and, in addition, the lowest concentrations in the Vltava at Solenice indicate that large amount of ${ }^{137} \mathrm{Cs}$ is deposited in the Orlík Reservoir. Values of the observed half-life of ${ }^{137} \mathrm{Cs}$ were in a range between 3.1 and 3.9 years. The current total concentrations are about $1 \mathrm{~Bq} / \mathrm{m}^{3}$, in both dissolved and suspended substances. In average, ecological half-life was 4.0 years.

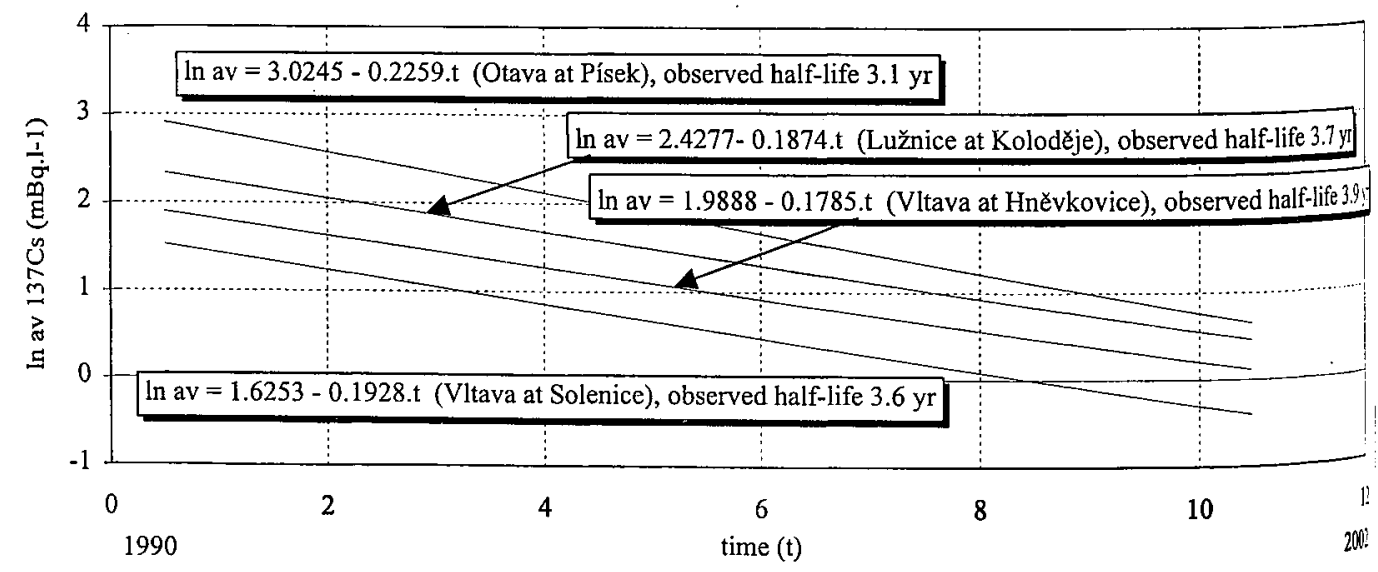

Figure 2: Time change in ${ }^{137} \mathrm{Cs}$ concentration (av) in surface water sampled from selected rivers.

Data on tritium concentrations in surface water in the vicinity of Temelín from the period 1991-2000 wer? used for derivation of a trend curve and prediction of the concentration for time period till 2010 (se? 
Figure 3). For the period when nuclear weapons were tested it was derived that the decrease in tritium concentration in surface water was relevant to radioactive decay with the half-fife of about 5 years. Since this period, the slope of the decrease has been decreasing, which is attributable to natural tritium occurrence responsible for about $0.4 \mathrm{~Bq} \cdot \mathrm{l}^{-1}\left(\mathrm{c}_{\mathrm{B}}\right)$ and tritium releases from nuclear facilities responsible for about $0.1 \mathrm{~Bq} \cdot 1^{-1}\left(\mathrm{c}_{\mathrm{ND}}\right)$. The decrease is presently at a level relevant to half-fife of about 10 years and the mean concentration is about $1.5 \mathrm{~Bq} \cdot \mathrm{l}^{-1}$.

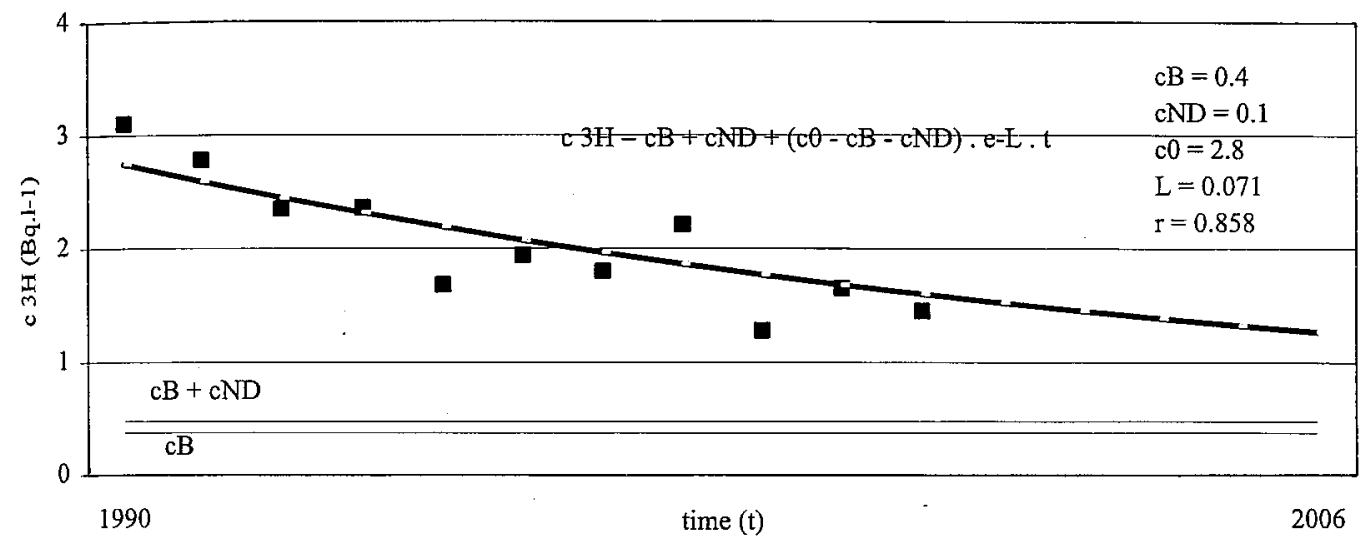

Figure 3: A trend curve predicting tritium concentration in surface water in the Temelín vicinity, derived from data observed in 1991-2000.

Figure 4 shows vertical distribution of ${ }^{226} \mathrm{Ra},{ }^{228} \mathrm{Ra}$ and ${ }^{137} \mathrm{Cs}$ in bottom sediments in the Orlík Reservoir in 1995. Maximum concentration of ${ }^{137} \mathrm{Cs}$ amounting to $820 \mathrm{~Bq} \cdot \mathrm{kg}^{-1}$ was observed in subsurface layer (in the depth between 10 and $15 \mathrm{~cm}$ ), which indicates that contamination resulting from the Chernobyl is overlaid. Concentrations of ${ }^{134} \mathrm{Cs},{ }^{137} \mathrm{Cs}$ and ${ }^{90} \mathrm{Sr}$ in the bottom sediments are high. It was calculated, that about $57 \mathrm{GBq}$ of ${ }^{137} \mathrm{Cs}$ is deposited in the upper $10 \mathrm{~cm}$ thick bottom layer in the Orlík Reservoir. However, the concentrations are decreasing with time. In 1990 , the average concentration of ${ }^{137} \mathrm{Cs}$ was $214 \mathrm{~Bq} \cdot \mathrm{kg}^{-1}\left({ }^{134} \mathrm{Cs}\right.$ of $26 \mathrm{~Bq} \cdot \mathrm{kg}^{-1}$ ), while it was $56 \mathrm{~Bq} \cdot \mathrm{kg}^{-1}$ in 2000 (concentration of ${ }^{134} \mathrm{Cs}$ was below 1.5 $\mathrm{Bq} . \mathrm{kg}^{-1}$ ). Concentration of naturally occurring radionuclides is constant both in time and in vertical profile (see ${ }^{226} \mathrm{Ra}$ and ${ }^{228} \mathrm{Ra}$ in Figure 4). In the period 1990-2000, the mean concentrations were $68 \mathrm{~Bq} \cdot \mathrm{kg}^{-1}$ of ${ }^{226} \mathrm{Ra}$ and $80 \mathrm{~Bq} \cdot \mathrm{kg}^{-1}$ of ${ }^{228} \mathrm{Ra}$.

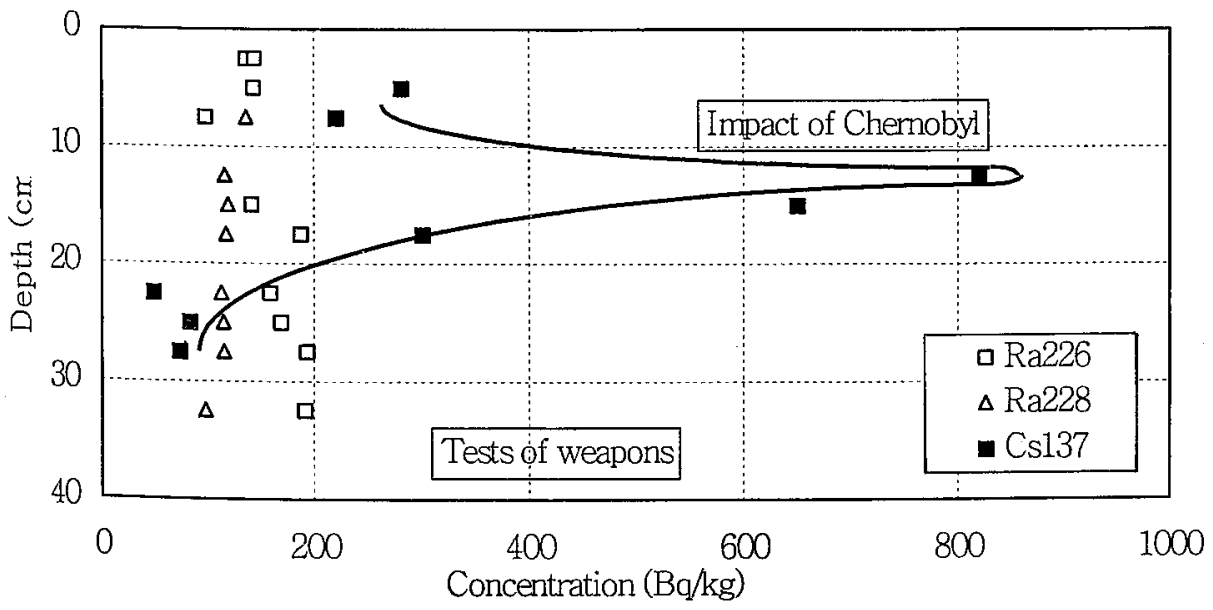

Figure 4 : Vertical distribution of concentrations of natural and artificial radionuclides in bottom sediments (dry weight) in the Orlik Reservoir in 1995. 
For the period 1986-2000, Figure 5 shows time change in mean annual concentrations of ${ }^{137} \mathrm{Cs}$ and ${ }^{134} \mathrm{Cs}$ in the bottom sediments and their ratio calculated from observed data and from the Chernobyl mixture. The observed half-life in the period $1990-2000$ was 6.0 and 1.6 years for ${ }^{137} \mathrm{Cs}$ and ${ }^{134} \mathrm{Cs}$ respectively. Ecological half-life was 7.7 for ${ }^{134} \mathrm{Cs}$ and 7.5 for ${ }^{137} \mathrm{Cs}$.

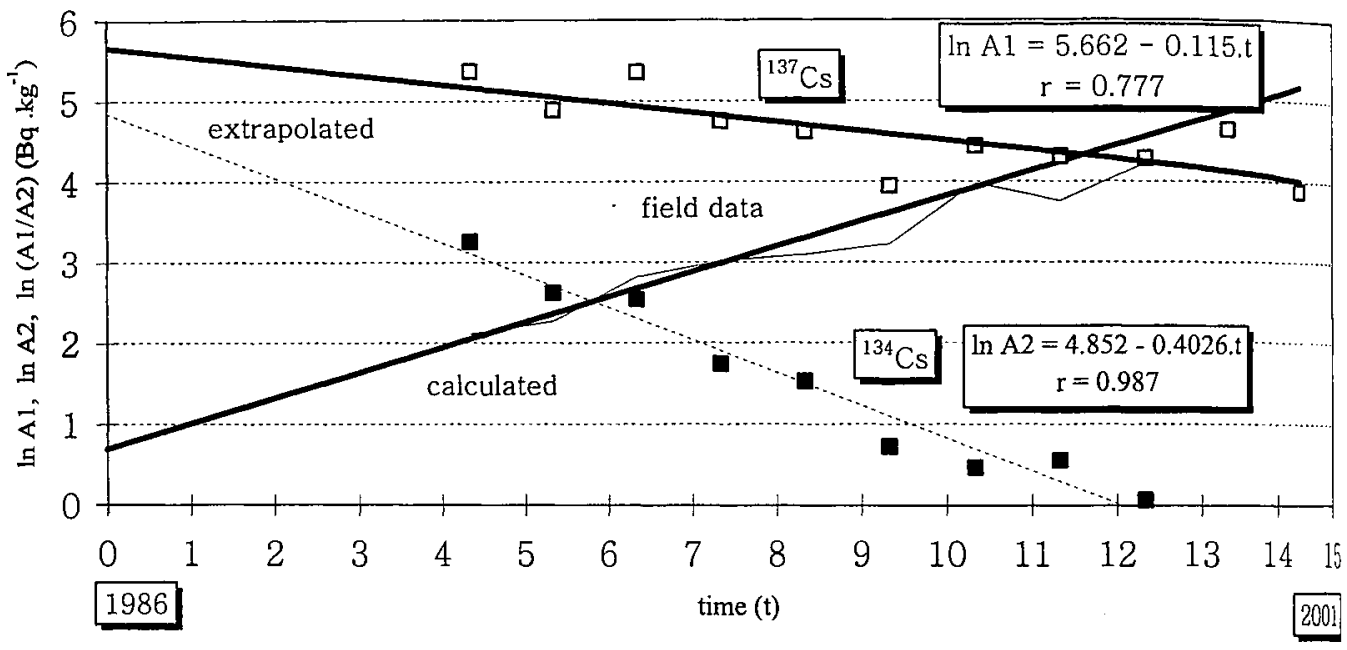

Figure 5 : Time change in mean annual concentrations of ${ }^{137} \mathrm{Cs}$ (A1) and ${ }^{134} \mathrm{Cs}$ (A2) in the bottom sediments in the Orlik Reservoir and their ratio, calculated from observed data and from the Chernobyl mixture.

For assessing conditions of surface waters under which productivity of aquatic ecosystems would not deteriorate and diversity of aquatic species would not significantly decrease, fish species and aquatic macrophytes were explored in the Orlik Reservoir. A peak after Chernobyl and subsequent decrease was observed also in the concentration of artificial radionuclides $\left({ }^{90} \mathrm{Sr},{ }^{134} \mathrm{Cs}\right.$ and ${ }^{137} \mathrm{Cs}$ ) in the biomass (dry weight). Time change in ${ }^{137} \mathrm{Cs}$ concentrations in fish sampled in Temelín vicinity is shown in Figure 6. In the period after Chernobyl, the observed half-life for both piscivorious and herbivorious fish species was about 2.8 years. Ecological half-life was 7.1 years.

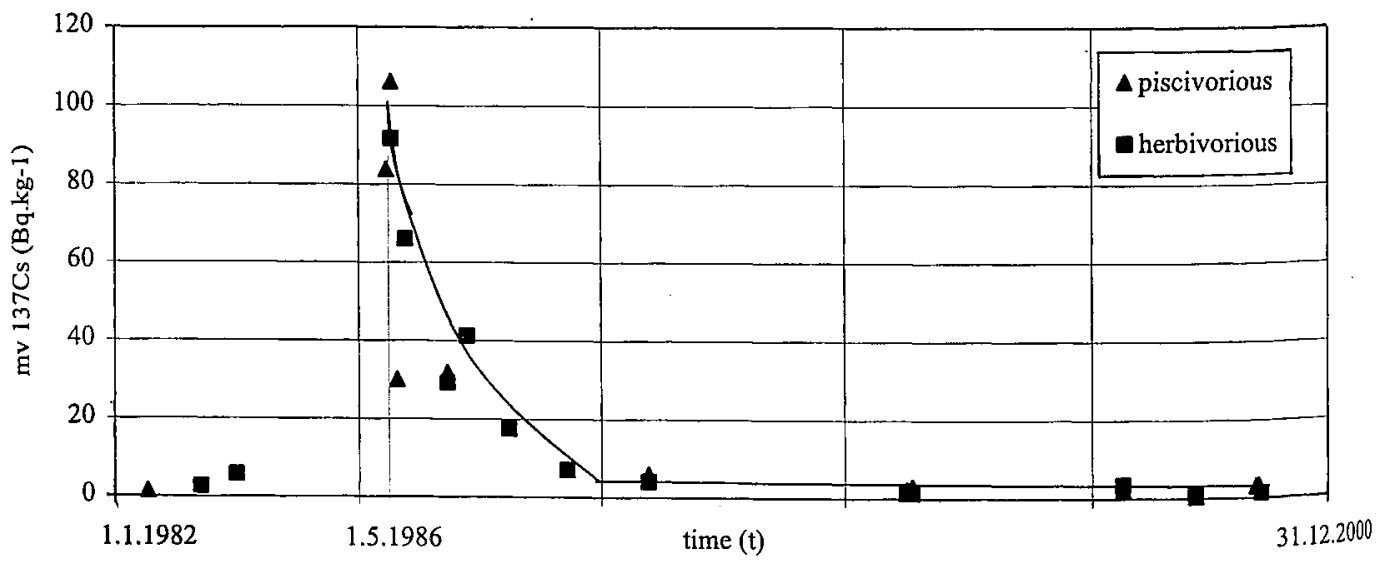

Figure 6 : Concentration of ${ }^{137} \mathrm{Cs}$ in fish sampled in Temelín NPP vicinity in the period $1982-2000$. 


\section{PREDICTION OF POSSIBLE IMPACTS}

In predicting the impact of standard operation of Temelín NPP on the Vltava River at Korensko, water quality observed at this site during 1998 and 1999 was taken as a reference level. As a consequence of the effluent returns discharged into the Vltava River at Kořensko, the concentration of polluting substances downstream from the outlet will increase by $3.5-43.1 \%$. This applies to $\mathrm{BOD}_{5}, \mathrm{COD}_{\mathrm{Mn}}, \mathrm{COD}_{\mathrm{Cr}}, \mathrm{Cl}^{-}$, $\mathrm{SO}_{4}{ }^{2-}$, dissolved substances, $\mathrm{Ca}^{2+}, \mathrm{N}_{-} \mathrm{NO}_{3}{ }^{-}, \mathrm{PO}_{4}{ }^{3-}$ and also to radioactive substances except for tritium. In terms of non-radioactive substances emitted from the plant under normal operation, the most important are the returns from the cooling system. The amount of these substances is proportional to quality of the abstracted water. This water, amounting for two reactors in average to $16001 . \mathrm{s}^{-1}$, will substantially be concentrated by evaporation, which is main causing factor of the water quality deterioration. However, water quality affected by the increased concentration of the polluting substances will not exceed pollution limits specified by Czech Government Decree 82/1997, which establishes indices for acceptable water pollution in the Czech Republic. A prediction of impact of waste water from Temelín NPP on average quality of water in the Vltava River at Kořensko and Prague is in Table 1.

Table 1

Emission limits as set out in Decision of District Authority in České Budějovice for selected water quality parameters in waste waters from Temelín NPP, and mean concentrations (observed in the period prior to the operation of the plant and increases predicted for an alternative when the polluting substances are discharged in amounts corresponding to the emission limits) of these substances for $\mathrm{Q}_{355}$ ( 355 day discharge from flow duration curve) in the Vltava River at Kořensko where the plant discharges the waste waters and at Prague where water is abstracted for water supply purposes.

\begin{tabular}{|c|c|c|c|c|c|c|c|}
\hline \multirow[t]{4}{*}{ Parameter } & \multirow{4}{*}{$\begin{array}{c}\text { Emission } \\
\text { limit } \\
\text { [ton.year-1] }\end{array}$} & \multicolumn{6}{|c|}{ River site } \\
\hline & & \multicolumn{3}{|c|}{$\begin{array}{c}\text { Kořensko } \\
Q_{355}=9.45 \mathrm{~m}^{3} \cdot \mathrm{s}^{-1}\end{array}$} & \multicolumn{3}{|c|}{$\begin{array}{c}\text { Prague } \\
\mathrm{Q}_{355}=40 \mathrm{~m}^{3} \cdot \mathrm{s}^{-1}\end{array}$} \\
\hline & & \multirow{2}{*}{\begin{tabular}{|l} 
Mean \\
concentration \\
{$\left[\right.$ mg. $\left.1^{-1}\right]$}
\end{tabular}} & \multicolumn{2}{|c|}{$\begin{array}{l}\text { Impact of NPP predicted } \\
\text { for the emission limits }\end{array}$} & \multirow{2}{*}{\begin{tabular}{|l} 
Mean \\
concentration \\
{$\left[\right.$ mg. $\left.\mathrm{I}^{-1}\right]$}
\end{tabular}} & \multicolumn{2}{|c|}{$\begin{array}{l}\text { Impact of NPP predicted } \\
\text { for the emission limits }\end{array}$} \\
\hline & & & {$\left[\mathrm{mg} \cdot \mathrm{I}^{-1}\right]$} & {$[\%]$} & & {$\left[\mathrm{mg} \cdot \mathrm{l}^{-1}\right]$} & {$[\%]$} \\
\hline $\mathrm{BOD}_{5}$ & 58 & 5.7 & 0.20 & 3.51 & 3.2 & 0.05 & 1.56 \\
\hline $\mathrm{COD}_{\mathrm{Mn}}$ & 148 & 8.7 & 0.49 & 5.63 & 5.9 & 0.12 & 2.54 \\
\hline $\mathrm{COD}_{\mathrm{Cr}}$ & 360 & 26.8 & 1.21 & 4.51 & 22.8 & 0.28 & 1.22 \\
\hline $\mathrm{Cl}^{\circ}$ & 1020 & 12.4 & 3.42 & 27.58 & 17.6 & 0.81 & 4.60 \\
\hline $\mathrm{SO}_{4}^{2 .}$ & 3850 & 30.0 & 12.92 & 43.07 & 46.7 & 3.05 & 6.54 \\
\hline Dissolved substances & 8600 & 148.0 & 28.85 & 19.49 & 198.7 & 6.82 & 3.43 \\
\hline $\mathrm{Ca}^{2+}$ & 1470 & 19.2 & 4.93 & 25.67 & 32.0 & 1.17 & 3.66 \\
\hline $\mathrm{N}-\mathrm{NO}_{3}^{-}$ & 58.8 & 1.6 & 0.2 & 12.5 & 3.5 & 0.05 & 1.43 \\
\hline $\mathrm{PO}_{4}^{3+}$ & 15 & 0.14 & 0.05 & 35.7 & 0.21 & 0.01 & 4.76 \\
\hline
\end{tabular}

Tritium is most important in terms of concentration of radioactive.substances. The authorised limit for tritium discharges in waste waters from the two reactors of the plant is $40 \mathrm{TBq} . \mathrm{yr}^{-1}$, while the limit for the remaining radionuclides is $1 \mathrm{GBq}_{\mathrm{yr}} \mathrm{r}^{-1}$. Figure 7 shows results of a prediction of tritium concentrations in longitudinal profile of the Vltava River for conditions of the operation of the two reactors and alternatively mean flow $\left(\mathrm{Q}_{\mathrm{m}}\right)$ and minimum flow $\left(\mathrm{Q}_{355}\right)$ in the river. For the minimum flow, the average concentrations of tritium downstream from the outlet from Temelín would increase by $133 \mathrm{~Bq} . \mathrm{l}^{-1}$, while short-term maxima could reach $550 \mathrm{~Bq} \cdot \mathrm{l}^{-1}$. However, these concentrations would be diluted by water from the Otava River and other tributaries and thus tritium average concentration in the Vltava River at Prague 
(the site where water is abstracted for drinking water supply purposes) will be at level relevant to $2 \%$ of the limit, which is $700 \mathrm{~Bq} . \mathrm{I}^{-1}$ for drinking water supply watercourses (Indicators III of Czech Government Decree 82/1997). Average concentration of tritium in the Elbe River at Hřensko (Czech-German boundary site), including the background level, will be around $5 \mathrm{~Bq} \cdot \mathrm{l}^{-1}$.

\section{CONCLUSIONS}

The results of the study demonstrate that quality of water in the Vltava River at Kořensko (the site where water is abstracted for Temelín NPP) is a dominating factor and its additional deterioration by pollution from Temelín would relatively be low. It is, therefore, important that the quality of water in the Vltava has significantly improved in the pre-operational period of the plant (this is attributable to newly constructed waste water treatment plants). Results of

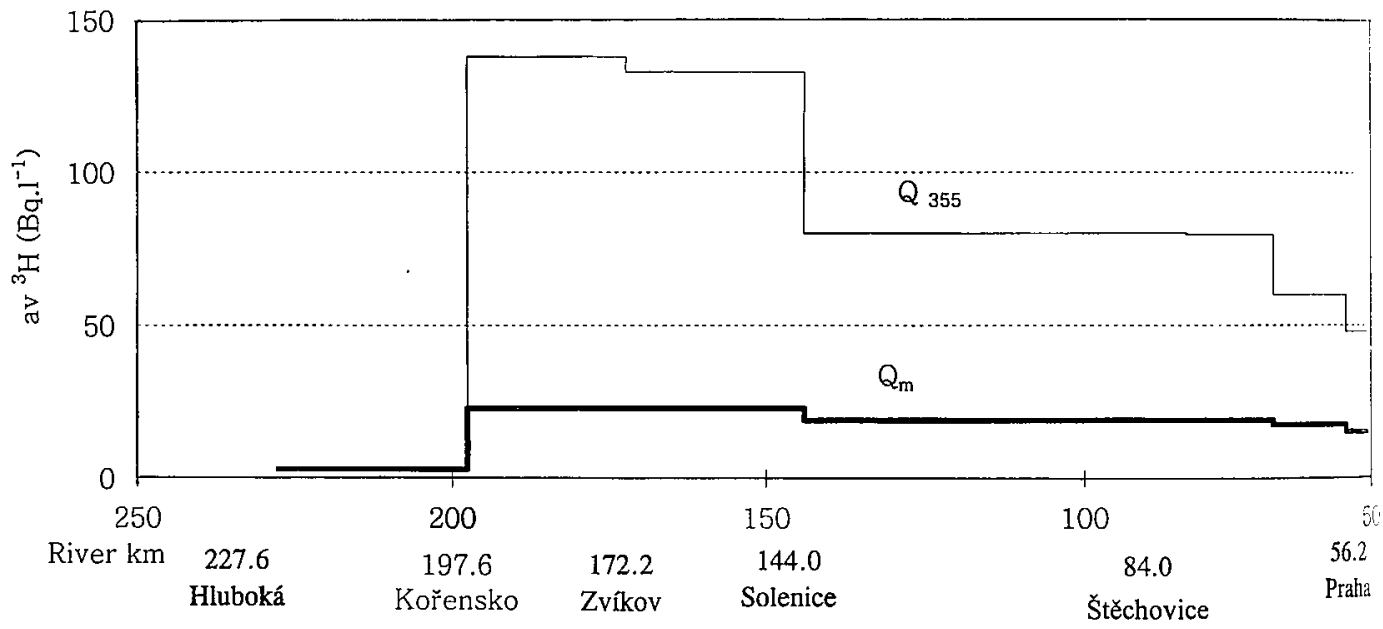

Figure 7 : Prediction of tritium concentration in longitudinal profile of the Vltava River for conditions of the operation of two reactors of Temelín NPP and mean flow $\left(Q_{m}\right)$ or minimum flow $\left(Q_{355}\right)$ in the river.

the prediction of impacts of the operation of Temelín NPP on hydrosphere indicate that pollution limits, as specified in the Czech Government Decree No. 82/1997, will not be exceeded.

Water quality deterioration is predicted in terms of tritium concentration, particularly in the Vltava River reach located directly downstream from the outlet of the waste and cooling water from the plant. However, the resulting concentration in Prague will be far below the limit specified for watercourses in use or intended to be used for drinking water supply purposes and thus the deterioration will not affect this use of the Vltava River in Prague. For Czech-German boundary site of the Elbe River at Hrensko, a fourfold increase in mean concentration of tritium is predicted as a consequence of the plant operation. However, the resulting concentration is relevant to $1 \%$ as compared of the above limit. Possible increases in concentrations of other radionuclides will not exceed levels of their concentrations in the period prior to the operation of the plant.

Data and results of the analyses conducted within the framework of the projects represent a reference level for future assessments of possible environmental changes resulting from the operation of Temelín NPP.

During the pilot operation of the first reactor of Temelín NPP in 2001, the discharged amounts and concentrations of both radioactive and non-radioactive substances have been far below the authorised limits. 


\section{References}

[1] Hanslík E. J.: Impact of Temelín Nuclear Power Plant on hydrosphere. Research for practice (series). Volume 35, TGM WRI Prague, 1997.

[2] Hanslík E. J. et al.: Výzkum vlivu jaderných zařízení na životní prostředí (Research on impact of nuclear facilities on the environment). Final report, TGM WRI Prague, 1998.

[3] Hanslík E. J. et al.: Sledování a hodnocení jakosti povrchových a podzemních vod a jejich změn v souvislosti s vlivem výstavby a provozu jaderné elektrárny Temelín na její okolí (Observation and assessments of quality of surface water and groundwater and its changes stemming from impacts of the construction and operation of Temelín NPP on its vicinity). Final report, TGM WRI Prague, 2000.

[4] IAEA: Evaluation of water resources monitoring. Report on assessment of analytical methods for radioactivity monitoring. RU-6172 (CZR/8/002), Vienna 1996. 